\title{
On Studying the Inter-relationships amongst the Challenges Faced by Traditional Handloom Industries of Bangladesh and India and the Success Factors behind the Digitization of these Industries to overcome these Barriers
}

\author{
Ratna Banerjee \\ School of Business, \\ University of Petroleum \& \\ Energy Studies \\ Dehradun, U.K.
}

\author{
Remica Aggarwal \\ MIT-SOER, MIT-ADT \\ University \\ Pune, India
}

\author{
Lakshay Aggarwal \\ Recventures Education \\ Services Private Limited \\ Delhi, India
}

\author{
V. K. Aggarwal \\ Recventures Education \\ Services Private Limited \\ Delhi, India
}

\begin{abstract}
In both the countries of Asia i.e. India as well as Bangladesh, handloom textiles constitute a timeless facet of the their rich cultural heritage. They occupy the second position only after agriculture in providing livelihood to the people. However despite the popularity, traditional handloom textiles faces many challenges especially in recent times which has paved the way for the digitization of handloom industries . Present research work explores both the challenges faced by traditional handloom weavers and industrial sector and how digitization and technology have helped in reshaping, renovating and upsell them.
\end{abstract}

\section{Keywords}

Solid waste management ; ISM methodology ; Incineration, Solid waste, Hazardous, Non-hazardous

\section{INTRODUCTION}

\subsection{Traditional Asian handloom industry : India and Bangladesh}

Handloom industry in India as well as Bangladesh have had glorious past. The art of weaving is perhaps as old as human civilization. Handloom textiles constitute a timeless facet of the rich cultural heritage of Bangladesh as well as India. As an economic activity, handloom sector occupies second only to agricultural sector in providing livelihood to the people. If talked about Bangladesh [7,11] , handloom sector of Bangladesh consists of more than 0.183 million handloom weavers of which about $50 \%$ are female workers $[4,10]$. Here also, this industry is the second largest source of rural employment in the country. Though the employment opportunity in this sector has been squeezed in the last 15 years, this sector is still offering employment to nearly 10 million weavers in rural area. Thus, a lot of researchers work for developing handloom industry. Bangladesh can proudly claim to have the best known and most popular specialty Jamdani, which is one of the varieties of the famous Dhaka Muslin or Mulmul [11]. With a manpower of more than 1.5 million weavers, dyers , hand-spinners, embroiders and artisans who are using their creative skills into more than 0.3 million active looms to produce about 620 million meters of fabric annually. Out of this, contributing about $63 \%$ of this towards home production, this industry contributes more than 10 billion taka annually to the national exchequer as value addition [8].

India International handwoven fair (IIHF) was conceptualized by handloom export council (HEPC) in 2011 to identify sustainable marketing solutions for the stakeholders of Indian handloom industry. Exports in textiles and apparel from India are expected to increase to USD 65 billion by 2016-17 from USD 40 billion in 2013-14. The total fabric production in India is expected to grow to 112 billion square metres by 2016-17 from 64 billion square metres in 2013-14 (Textiles and Garments-Make in India.com) ${ }^{1}$. By now, the country supplies $95 \%$ of world demand for hand-woven fabric (Handloom Industry of India: www.ibef.org/exports/handloom-industry-india) ${ }^{2}$. The ikat or tie and dye fabrics with intricate and artistic designs, produced in leading handloom clusters of India play a vital role in export market and attract foreign consumers to its market sphere . The 'Patola' [13], double ikat silk sari of 'Patan' [14], Pagdu Bandhu, Buddavasi and Chiticki [15] and Bandha [16], are now world famous due to their quality, craftsmanship and design characteristics. Odisha ikat ranks one among other ikat producing states in India.

Despite such popularity, the traditional handloom textile sector still faces a series of barriers which have been explored in the present research work .

\subsection{Digitization of handloom industry}

It may be one of the oldest trade, but the textile industry has come a long way from the early days of handcrafting. Once considered a labor intensive craft, textiles has now become a heavily technology driven process due to the advancement in Predictive Analytics, IoT, Artificial Intelligence and ERP. It opens a pool of opportunities for textile players to achieve Industry 4.0 leadership and deliver automated control over the textile fabrication process from design and coloring to fiber construction, fabric creation, finishing and delivery. Digital media like mobile web, mobile apps and social media are changing consumer awareness and buying behavior rapidly. Facebook crossed the 2.2 billion active users mark recently in 2018. Twitter has 335 million monthly users. Pinterest has over 150 million active users. There are more than 6 million mobile phone applications. Digital platforms (DP) have the potential to innovate and scale up volumes of Indian handloom products both in the domestic and international 
markets. This therefore has the potential for large scale employment to over 4 million weavers spread all over the country in rural \& semi-rural areas . In the new Digital economy, top class digital platforms could be the ' $x$-factor' that will catalyze the widespread usage and growth of traditional handlooms. Present research therefore also focuses on various $x$ factors or success factors that can contribute towards the successful digitization of Indian handloom textile industry

Present research work is arranged as follows. Section 2 is based on literature review of the handloom industry of India and Bangladesh. Section 3 presents the ISM methodology . Section 4 presents the case examples in two sections. In section 4.1 , it studies the interrelationship amongst the various barriers to traditional handloom weavers of India and Bangladesh and the inter-relationship amongst them through ISM methodology. In section 4.2, the interrelationships amongst the various success factors to digitization of Indian handloom industry has been studied through ISM methodology. Future Directions are provided in section 5.

\section{LITERATURE REVIEW}

\subsection{Handloom industry challenges in Bangladesh [1-12]}

2.1.1 Fear of communal violence and lack of security (FCV): Banarjee et al. [1], tried to identify the causes of weaver migration from Bangladesh to India. They identified the factors like fear of communal violence, increased price of raw materials, absence of loan from government, insufficient transport facility, better facilities in India, lack of security for their rapid migration to India.

2.1.2 Weak technical efficiency (WTE): Jaforulla [14] showed that technical efficiency of handloom industry of Bangladesh is only $41 \%$ ad can be improved by increasing its male and female labor ratio and decreasing its hired/family labor ratio and labor-capital ratio.

2.1.3 Lack of policy support (LPS): Ghosh and Akter [10], in their research have identified those predominant factors that are moving the wheels of this industry slowly. They have found that shortage of working capital, high cost of raw material procurement, lack of organizing capability, inadequate technology and efficiency, and lack of policy support are major forces which are bitterly hit the handloom industry.

2.1.4 Technical inefficiency (TI): Islam and Hossain [7] analyzed the technical inefficiency of handloom industry. They have found that education, experience, size of units, and age of owners are significant factors inflowing technical inefficiency of handloom industry.

2.1.5 Scarcity of working capital (SWC): Weavers are suffering from inadequate contemporary technology and scarcity of working capital. These are mandatory to maintain the smooth flow of production [2]. But, weavers suffer from scarcity of working capital. Most of the time, weavers acquire their working capital from their own money and sometimes they acquire capital from various situations like govt. banks, private banks and some other financial institutions.

2.1.6 Lack of quality raw materials (LOQTM): Weavers in our country don't get quality raw materials at right time and at right price. The issue of easy sourcing of raw materials (both yarn and dyes \& chemicals) at reasonable prices has been a key problem across centers of handloom production. In recent years, there has been a phenomenal rise in the prices of yarn. The main reason for this is the sharp increase in the prices of cotton.

2.1.7 Lack of proper delivery systems [LPDS]: Closure of spinning mills in some handloom producing zone and non- fulfilment of the Hank Yarn obligation by the organized mill sector. According to Handloom Census, 2003 more than $12 \%$ handloom units shut down their production due to lack of yarn.

2.1.8 Inability to choose the optimal combination of inputs (IOCI) : Due to lack of higher education, skill, experience, training and well management capacity, the owners fail to minimize input use to produce a certain level of output. This failure makes their units less profitable and hence, they are forced to close down their units over time.

2.1.9 Poor marketing and insufficient market linkage (PMIML) : Most of the handloom product markets are located in special region. For example, in Bangladesh, markets for Jamdani are located in Narayangonj zone whereas markets for Tangail Sharee are located in Tangail district. On the other hand, most of the buyers are not concern about the quality and the price of different products.

2.1.10 Lack of information (LoI): Weavers are less informed regarding various Government policies and schemes under implementation. Sometimes, the implementing agencies and the concerned governments departments themselves may not possess complete information, resulting in critical gaps in implementation.

2.1.11 Inadequate infrastructure (II): Facilities such as clean drinking water, sanitation, effluent treatment plants and electricity, are not available in all hubs of handlooms production. Systems that ensure efficient supply chain management from the stage of availability of handloom raw materials up to sale of finished goods, essential for providing the weavers easy access to inputs and markets throughout the country.

2.1.12 Lower income and instable work (LIUW): The younger generation of weavers suffer from scarcity of working capital. Most of the time, weavers acquire their working capital from their own money and sometimes they acquire capital from various in situations like govt. banks, private banks and some other financial institutions in higher interest and various difficult conditions.

2.1.13 High incidence of poverty and illiteracy (HIPI) : The high incidence of poverty and illiteracy among weaver families is accompanied by poor access to basic necessities including health, water, sanitation, housing and livelihood facilities.

2.1.14 Poor role of women (PRW): The role of women in the handloom industry is largely unacknowledged. But this sector derives a majority of its skills and work from women who constitute about $50 \%$ of weavers and workers engaged in this sector. Although in some regions, women may not specifically take up weaving work, they are engaged in the production process right from the initial stage of opening up the hank to the finishing of the product.

2.1.15 Poor level of skills (PLS): High level of skill is needed to produce handloom products, but weavers are unskilled or semi-skilled. At the same time, there is no development program for weavers. So various specialized trainings program should be launched for weavers that will 
keep them updated. Both private and public sectors can work for this.

\subsection{Factors boosting digitization 5}

2.2.1 Online digital platform (ODP) : Weaving a fine handloom saree or lengths of material for kurtas/salwars/lehengas is a time-consuming process. In order to upsell and market authentic handloom products, creative packaging and showcasing becomes absolutely essential . Online digital platforms with the advantage of beautiful digital visuals and worldwide reach can upsell and highlight the natural beauty and intricacy of handloom products very well. The market for beautiful handloom products is spread across the length and breadth of India - metros, mini metros, Tier I and II towns.

2.2.2 Growing consciousness (GC) : With the increase in consumer consciousness of well-made apparel and well accessibility to the internet, Indian women find it much easier to search and buy the products they want on their favorite websites.

2.2.3 Wider internet platform (WIP) : The internet/world wide web provides a platform that makes it possible to reach all segments of customers in large numbers. It is estimated that in India over 500 million people had access to the internet by the end of 2018 .

2.2.4 Established online businesses(EOB): Established online businesses which are committed to the welfare of the weaving community offer customers the opportunity to browse beautiful handloom products at leisure, ask questions and buy the product of their choice, at a convenient time from the comfort of their homes or offices

2.2.5 E-Commerce platform (Ecom-P) : There are few ECommerce platforms that are touching lives of more than 1000 weavers every month in a mission to democratize access to fine Indian handlooms sourced from a plethora of weaving clusters across the country.

2.2.6 Higher customer expectations and behavior (HCE/B) : For starters, consumers behavior and expectations have changed dramatically. Today's digitally connected consumers expects high quality products . However , personalized, value added services have shifted from traditionally premium offerings to assumed ones. In addition, technological possibilities have increased dramatically since the last industrial revolution, delivering substantial improvements in speed, precision, quality and supply chain visibility to the consumers.

2.2.7 Digital transformation strategy (DTS) : It is easy to get caught up in the short and long term benefits the digital transformation can deliver -reduced handling costs, predictive capabilities, activity based costing, before actually understanding what it takes to get there. Large scale business ventures require careful planning and digital transformation is no exception.

2.2.8 Clear mission and specific objectives (CM/SO) : Your organization should have the clear mission with specific objectives that outline your expectations and lay out the scope and volume of your digital transition such as changes to structural and decorative design process, legacy system updates , cost/benefit analyses and supply chain partnerships

2.2.9 Treat data as an asset (TDA) : While they are primarily known for producing thousands of pounds of textiles daily, mills also have the potential to generate massive amount of valuable data. The key for any textile company looking to establish itself as digital leader is to view this information as an irreplaceable commodity. After all, ineffective sourcing processes, limited supply chain visibility poor sustainability management and subcontractor integration and disconnected financial systems are all issues that begin and end with poor data utilization

2.2.10 Advancement in digital technology (ADT): Advancements in digital technology have pushed industries past the point where data can be ignored . Tailored platform solutions enable automation in all aspects of textile fabrication - from design and coloring to fiber construction and optimize asset utilization and productivity . Global organizations have taken notice, as digital transformation initiatives in textiles are becoming more widespread as companies grapple for market control.

2.2.11 Customer centric approach (CCA): Textiles comes in endless variations. Historically, product standardization has been the go-to strategy for companies looking to maintain profits. However, this approach doesn't always provide the best fit for the customer. Organizations now need to draw value from the data generated by thousands of individual transactions and use this information to power quick order completion via tailor made solutions. Market players must embrace this customer - centric approach and digital technology is crucial to support complex data processing that helps them do so.

2.2.12 Executive must embrace change (EC) : In the next few years, more investment in management platforms and data monitoring tools could be seen in the textile industry. The right systems will help businesses judge customer demand with greater accuracy and help deliver value-added features or individualized aspects in their products, boosting customer relationships and brand loyalty in the process

\section{INTERPRETIVE STRUCTURAL MODELLING METHODOLOGY}

Proposed by Warfield [17], ISM methodology is a technique for establishing inter-relationships amongst the criteria of interest. The process begins with the identification of relevant elements and thereafter establishing contextual relationship amongst them . After that, the structural self- interaction matrix is created using the VAXO concept which is then followed by the creation of initial reachability matrix . Final reachability matrix is then created after correcting the initial reachability matrix for any possibility of transitivity. From the reachability matrix, the reachability set and antecedent set for each criterion is found. Then the intersection of these sets is derived for all elements. The element for which the reachability and intersection sets are the same is the top-level element. Then the reachability matrix is converted into the canonical matrix format by arranging the elements according to their levels. Based on the relative driving power and dependence power, factors are classified in various categories like autonomous, dependent, driver and linkage. Finally, a diagraph is constructed from the canonical matrix .

\section{CASE EXAMPLE}

\subsection{Case 1 : Barriers to traditional handloom industry}

The 14 metrics viz. Fear of communal violence and lack of security (FCV); Lack of policy support (LPS); Technical inefficiency (TI); Scarcity of working capital (SWC); Lack of 
quality raw materials (LOQRM) ; Lack of proper delivery systems [LPDS] ; Inability to choose the optimal combination of inputs (IOCI) ; Poor marketing and insufficient market linkage (PMIML) ; Lack of information (LoI) ; Inadequate infrastructure (II) ; Lower income and instable work (LIUW) ; High incidence of poverty and illiteracy (HIPI); Poor role of women (PRW) ; Poor level of skills (PLS) are now studied for possible inter-relationship amongst them using ISM methodology

\subsection{Case 2 : Success factors behind digitization of handloom industry}

Fig 4.1.1: SSIM matrix for pair wise relationship amongst barriers

\begin{tabular}{|c|c|c|c|c|c|c|c|c|c|c|c|c|c|c|c|}
\hline S. No. & Barriers & 1 & 2 & 3 & 4 & 5 & 6 & 7 & 8 & 9 & 10 & 11 & 12 & 13 & 14 \\
\hline & & FCV & LPS & TI & SWC & $\begin{array}{c}\text { LOQ } \\
\text { RM }\end{array}$ & $\begin{array}{c}\text { LPD } \\
\text { S }\end{array}$ & IOCI & $\begin{array}{l}\text { PMI } \\
\text { ML }\end{array}$ & LOI & II & $\begin{array}{c}\text { LIU } \\
\text { W }\end{array}$ & $\begin{array}{c}\text { HIP } \\
\text { I }\end{array}$ & $\begin{array}{l}\text { PR } \\
\text { W }\end{array}$ & $\begin{array}{c}\text { PL } \\
\text { S }\end{array}$ \\
\hline 1 & FCV & & V & $\mathrm{V}$ & V & V & $\mathrm{V}$ & $\mathrm{V}$ & V & $\mathrm{V}$ & $\mathrm{V}$ & $\mathrm{V}$ & V & $\mathrm{V}$ & V \\
\hline 2 & LPS & & & V & V & V & V & V & V & V & V & V & V & V & V \\
\hline 3 & TI & & & & A & V & V & V & V & $\mathrm{X}$ & A & $\mathrm{A}$ & A & A & A \\
\hline 4 & SWC & & & & & V & V & V & V & V & V & A & A & A & A \\
\hline 5 & LOQRM & & & & & & A & A & A & A & A & A & A & A & A \\
\hline 6 & LPDS & & & & & & & $\mathrm{O}$ & $\mathrm{X}$ & A & A & A & A & A & A \\
\hline 7 & IOCI & & & & & & & & A & A & A & A & A & A & A \\
\hline 8 & PMIML & & & & & & & & & A & A & A & A & A & A \\
\hline 9 & LOI & & & & & & & & & & V & V & V & V & $\mathrm{V}$ \\
\hline 10 & II & & & & & & & & & & & $\mathrm{V}$ & V & V & V \\
\hline 11 & $\begin{array}{l}\text { LIUW } \\
\end{array}$ & & & & & & & & & & & & $\mathrm{A}$ & $\mathrm{V}$ & V \\
\hline 12 & HIPI & & & & & & & & & & & & & V & V \\
\hline 13 & PRW & & & & & & & & & & & & & & $\mathrm{V}$ \\
\hline 14 & PLS & & & & & & & & & & & & & & \\
\hline
\end{tabular}

Fig 4.1.2: Initial reachability matrix

\begin{tabular}{|c|c|c|c|c|c|c|c|c|c|c|c|c|c|c|c|}
\hline S. No. & Barriers & 1 & 2 & 3 & 4 & 5 & 6 & 7 & 8 & 9 & 10 & 11 & 12 & 13 & 14 \\
\hline & & FCV & LPS & TI & SWC & $\begin{array}{c}\text { LOQ } \\
\text { RM }\end{array}$ & $\begin{array}{c}\text { LP } \\
\text { DS }\end{array}$ & IOCI & $\begin{array}{c}\text { PMI } \\
\text { ML }\end{array}$ & LOI & II & $\begin{array}{c}\text { LIU } \\
\text { W }\end{array}$ & $\begin{array}{c}\text { HIP } \\
\text { I }\end{array}$ & $\begin{array}{c}\text { PR } \\
\text { W }\end{array}$ & $\begin{array}{c}\text { PL } \\
\text { S }\end{array}$ \\
\hline 1 & FCV & 1 & 1 & 1 & 1 & 1 & 1 & 1 & 1 & 1 & 1 & 1 & 1 & 1 & 1 \\
\hline 2 & LPS & 0 & 1 & 1 & 1 & 1 & 1 & 1 & 1 & 1 & 1 & 1 & 1 & 1 & 1 \\
\hline 3 & TI & 0 & 0 & 1 & 0 & 1 & 1 & 1 & 1 & 1 & 0 & 0 & 0 & 0 & 0 \\
\hline 4 & SWC & 0 & 0 & 1 & 1 & 1 & 1 & 1 & 1 & 1 & 1 & 0 & 0 & 0 & 0 \\
\hline 5 & LOQRM & 0 & 0 & 0 & 0 & 1 & 0 & 0 & 0 & 0 & 0 & 0 & 0 & 0 & 0 \\
\hline 6 & LPDS & 0 & 0 & 0 & 0 & 0 & 1 & 0 & 1 & 0 & 0 & 0 & 0 & 0 & 0 \\
\hline 7 & IOCI & 0 & 0 & 0 & 0 & 0 & 0 & 1 & 0 & 0 & 0 & 0 & 0 & 0 & 0 \\
\hline 8 & PMIML & 0 & 0 & 0 & 0 & 1 & 1 & 1 & 1 & 0 & 0 & 0 & 0 & 0 & 0 \\
\hline 9 & LOI & 0 & 0 & 1 & 0 & 0 & 1 & 1 & 1 & 1 & 1 & 1 & 1 & 1 & 1 \\
\hline 10 & II & 0 & 0 & 1 & 0 & 0 & 1 & 1 & 1 & 0 & 1 & 1 & 1 & 1 & 1 \\
\hline 11 & LIUW & 0 & 0 & 1 & 1 & 0 & 1 & 1 & 1 & 0 & 0 & 1 & 0 & 1 & 1 \\
\hline
\end{tabular}

The 12 success factors are considered viz. Online digital platform (ODP) ; Growing consciousness (GC) ; Wider internet platform (WIP) ; Established online businesses (EOB) ; E-Commerce platform (ECom-P) ; Higher customer expectations and behavior $(\mathrm{HCE} / \mathrm{B})$; Digital transformation strategy (DTS) ; Clear mission and specific objectives $(\mathrm{CM} / \mathrm{SO})$; Treat data as an asset (TDA) ; Advancement in digital technology (ADT) ; Customer centric approach (CCA) ; Promotion of change (PC) are now studied for possible inter-relationship amongst them using ISM methodology . 


\begin{tabular}{|c|c|c|c|c|c|c|c|c|c|c|c|c|c|c|c|}
\hline 12 & HIPI & 0 & 0 & 1 & 1 & 0 & 1 & 1 & 1 & 0 & 0 & 1 & 1 & 1 & 1 \\
\hline 13 & PRW & 0 & 0 & 1 & 1 & 0 & 1 & 1 & 1 & 0 & 0 & 0 & 0 & 1 & 1 \\
\hline 14 & PLS & 0 & 0 & 1 & 1 & 0 & 1 & 1 & 1 & 0 & 0 & 0 & 0 & 0 & 1 \\
\hline
\end{tabular}

Fig 4.1.3 : Final reachability matrix

\begin{tabular}{|c|c|c|c|c|c|c|c|c|c|c|c|c|c|c|c|c|}
\hline S. No. & Barriers & 1 & 2 & 3 & 4 & 5 & 6 & 7 & 8 & 9 & 10 & 11 & 12 & 13 & 14 & D.P \\
\hline & & FCV & LPS & TI & $\begin{array}{c}\text { SW } \\
\text { C }\end{array}$ & $\begin{array}{c}\text { LOQ } \\
\text { RM }\end{array}$ & $\begin{array}{l}\text { LP } \\
\text { DS }\end{array}$ & IOCI & $\begin{array}{l}\text { PMI } \\
\text { ML }\end{array}$ & LOI & II & $\begin{array}{c}\text { LIU } \\
\text { W }\end{array}$ & $\begin{array}{c}\text { HIP } \\
\text { I }\end{array}$ & $\begin{array}{l}\text { PR } \\
W\end{array}$ & $\begin{array}{c}\text { PL } \\
\text { S }\end{array}$ & \\
\hline 1 & FCV & 1 & 1 & 1 & 1 & 1 & 1 & 1 & 1 & 1 & 1 & 1 & 1 & 1 & 1 & 14 \\
\hline 2 & LPS & 0 & 1 & 1 & 1 & 1 & 1 & 1 & 1 & 1 & 1 & 1 & 1 & 1 & 1 & 13 \\
\hline 3 & TI & 0 & 0 & 1 & 0 & 1 & 1 & 1 & 1 & 1 & 1 & 1 & 1 & 1 & 1 & 10 \\
\hline 4 & SWC & 0 & 0 & 1 & 1 & 1 & 1 & 1 & 1 & 1 & 1 & 1 & 1 & 1 & 1 & 12 \\
\hline 5 & LOQRM & 0 & 0 & 0 & 0 & 1 & 0 & 0 & 0 & 0 & 0 & 0 & 0 & 0 & 0 & 1 \\
\hline 6 & LPDS & 0 & 0 & 0 & 0 & 1 & 1 & 1 & 1 & 0 & 0 & 0 & 0 & 0 & 0 & 3 \\
\hline 7 & IOCI & 0 & 0 & 0 & 0 & 1 & 0 & 1 & 0 & 0 & 0 & 0 & 0 & 0 & 0 & 1 \\
\hline 8 & PMIML & 0 & 0 & 0 & 0 & 1 & 1 & 1 & 1 & 0 & 0 & 0 & 0 & 0 & 0 & 3 \\
\hline 9 & LOI & 0 & 0 & 1 & 0 & 1 & 1 & 1 & 1 & 1 & 1 & 1 & 1 & 1 & 1 & 10 \\
\hline 10 & II & 0 & 0 & 1 & 0 & 1 & 1 & 1 & 1 & 1 & 1 & 1 & 1 & 1 & 1 & 10 \\
\hline 11 & LIUW & 0 & 0 & 1 & 1 & 1 & 1 & 1 & 1 & 1 & 1 & 1 & 0 & 1 & 1 & 11 \\
\hline 12 & HIPI & 0 & 0 & 1 & 1 & 1 & 1 & 1 & 1 & 1 & 1 & 1 & 1 & 1 & 1 & 10 \\
\hline 13 & PRW & 0 & 0 & 1 & 1 & 1 & 1 & 1 & 1 & 1 & 1 & 0 & 0 & 1 & 1 & 9 \\
\hline \multirow[t]{2}{*}{14} & PLS & 0 & 0 & 1 & 1 & 1 & 1 & 1 & 1 & 1 & 1 & 0 & 0 & 0 & 1 & 8 \\
\hline & De.P & 1 & 2 & 10 & 7 & 14 & 12 & 14 & 12 & 10 & 10 & 8 & 8 & 9 & 10 & \\
\hline
\end{tabular}

D.P : Driving power ; De.P : dependence power

\begin{tabular}{|c|c|c|c|c|c|c|c|c|c|c|c|c|c|}
\hline $\begin{array}{c}\text { S. } \\
\text { No. }\end{array}$ & Barriers & 1 & 2 & 3 & 4 & 5 & 6 & 7 & 8 & 9 & 10 & 11 & 12 \\
\hline & & ODP & GC & WIP & EOB & $\begin{array}{l}\text { Eco } \\
\text { m-P }\end{array}$ & $\begin{array}{c}\mathrm{HCE} \\
/ \mathrm{B}\end{array}$ & DTS & $\begin{array}{c}\mathrm{CM} / \\
\mathrm{SO}\end{array}$ & $\begin{array}{c}\text { TD } \\
\text { A }\end{array}$ & $\begin{array}{c}\mathrm{AD} \\
\mathrm{T}\end{array}$ & $\begin{array}{c}\mathrm{CC} \\
\mathrm{A}\end{array}$ & $\mathrm{PC}$ \\
\hline 1 & ODP & & A & A & A & A & A & A & $\mathrm{A}$ & A & A & $\mathrm{A}$ & A \\
\hline 2 & GC & & & $\mathrm{V}$ & $\mathrm{A}$ & V & $\mathrm{V}$ & $\mathrm{V}$ & $\mathrm{V}$ & $\mathrm{V}$ & $\mathrm{V}$ & $\mathrm{V}$ & $\mathrm{V}$ \\
\hline 3 & WIP & & & & $\mathrm{A}$ & $\mathrm{A}$ & $\mathrm{A}$ & $\mathrm{A}$ & $\mathrm{A}$ & $\mathrm{A}$ & $\mathrm{A}$ & V & $\mathrm{V}$ \\
\hline 4 & EOB & & & & & $\mathrm{V}$ & $\mathrm{A}$ & $\mathrm{X}$ & $\mathrm{V}$ & $\mathrm{V}$ & $\mathrm{V}$ & $\mathrm{V}$ & $\mathrm{V}$ \\
\hline 5 & Ecom-P & & & & & & A & A & $\mathrm{A}$ & $\mathrm{A}$ & $\mathrm{A}$ & V & A \\
\hline 6 & HCE/B & & & & & & & $\mathrm{V}$ & $\mathrm{X}$ & $\mathrm{V}$ & $\mathrm{V}$ & $\mathrm{V}$ & $\mathrm{V}$ \\
\hline 7 & DTS & & & & & & & & A & V & V & V & V \\
\hline 8 & $\mathrm{CM} / \mathrm{SO}$ & & & & & & & & & V & V & V & V \\
\hline 9 & TDA & & & & & & & & & & A & V & A \\
\hline 10 & ADT & & & & & & & & & & & $X$ & V \\
\hline 11 & CCA & & & & & & & & & & & & V \\
\hline 12 & $\mathrm{PC}$ & & & & & & & & & & & & \\
\hline
\end{tabular}


Fig 4.2.1: SSIM matrix for pair wise relationship amongst barriers

\begin{tabular}{|c|c|c|c|c|c|c|c|c|c|c|c|c|c|}
\hline S. & Barriers & 1 & 2 & 3 & 4 & 5 & 6 & 7 & 8 & 9 & 10 & 11 & 12 \\
\hline & & ODP & GC & WIP & EOB & $\begin{array}{l}\text { Eco } \\
\text { m-P }\end{array}$ & $\begin{array}{c}\mathrm{HCE} \\
/ \mathrm{B}\end{array}$ & DTS & $\begin{array}{c}\mathrm{CM} / \\
\mathrm{SO}\end{array}$ & $\begin{array}{c}\text { TD } \\
\text { A }\end{array}$ & $\begin{array}{c}\mathrm{AD} \\
\mathrm{T}\end{array}$ & $\begin{array}{c}\mathrm{CC} \\
\mathrm{A}\end{array}$ & PC \\
\hline 1 & ODP & 1 & 0 & 0 & 0 & 0 & 0 & 0 & 0 & 0 & 0 & 0 & 0 \\
\hline 2 & GC & 0 & 1 & 1 & 0 & 1 & 1 & 1 & 1 & 1 & 1 & 1 & 1 \\
\hline 3 & WIP & 1 & 0 & 1 & 0 & 0 & 0 & 0 & 0 & 0 & 0 & 1 & 1 \\
\hline 4 & EOB & 1 & 1 & 1 & 1 & 1 & 0 & 1 & 1 & 1 & 1 & 1 & 1 \\
\hline 5 & Ecom-P & 1 & 0 & 1 & 0 & 1 & 0 & 0 & 0 & 0 & 0 & 1 & 0 \\
\hline 6 & $\mathrm{HCE} / \mathrm{B}$ & 1 & 0 & 1 & 1 & 1 & 1 & 1 & 1 & 1 & 1 & 1 & 1 \\
\hline 7 & DTS & 1 & 0 & 1 & 1 & 1 & 0 & 1 & 0 & 1 & 1 & 1 & 1 \\
\hline 8 & $\mathrm{CM} / \mathrm{SO}$ & 1 & 0 & 1 & 0 & 1 & 1 & 1 & 1 & 1 & 1 & 1 & 1 \\
\hline 9 & TDA & 1 & 0 & 1 & 0 & 1 & 0 & 0 & 0 & 1 & 0 & 1 & 0 \\
\hline 10 & ADT & 1 & 0 & 1 & 0 & 1 & 0 & 0 & 0 & 1 & 1 & 1 & 1 \\
\hline 11 & CCA & 1 & 0 & 0 & 0 & 0 & 0 & 0 & 0 & 0 & 1 & 1 & 1 \\
\hline 12 & PC & 1 & 0 & 0 & 0 & 1 & 0 & 0 & 0 & 1 & 0 & 0 & 1 \\
\hline
\end{tabular}

Fig 4.2.2: Initial reachability matrix

\begin{tabular}{|c|c|c|c|c|c|c|c|c|c|c|c|c|c|c|}
\hline $\begin{array}{c}\text { S. } \\
\text { No. }\end{array}$ & Barriers & 1 & 2 & 3 & 4 & 5 & 6 & 7 & 8 & 9 & 10 & 11 & 12 & D.P \\
\hline & & ODP & GC & WIP & EOB & $\begin{array}{l}\text { Eco } \\
\mathrm{m}-\mathrm{P}\end{array}$ & $\begin{array}{c}\mathrm{HCE} \\
/ \mathrm{B}\end{array}$ & DTS & $\begin{array}{c}\mathrm{CM} / \\
\mathrm{SO}\end{array}$ & $\begin{array}{c}\text { TD } \\
\text { A }\end{array}$ & $\begin{array}{c}\mathrm{AD} \\
\mathrm{T}\end{array}$ & $\begin{array}{c}\mathrm{CC} \\
\mathrm{A}\end{array}$ & PC & \\
\hline 1 & ODP & 1 & 0 & 0 & 0 & 0 & 0 & 0 & 0 & 0 & 0 & 0 & 0 & 1 \\
\hline 2 & $\mathrm{GC}$ & 1 & 1 & 1 & 1 & 1 & 1 & 1 & 1 & 1 & 1 & 1 & 1 & 10 \\
\hline 3 & WIP & 1 & 0 & 1 & 0 & 1 & 0 & 0 & 0 & 1 & 1 & 1 & 1 & 7 \\
\hline 4 & EOB & 1 & 1 & 1 & 1 & 1 & 0 & 1 & 1 & 1 & 1 & 1 & 1 & 11 \\
\hline 5 & Ecom-P & 1 & 0 & 1 & 0 & 1 & 0 & 0 & 0 & 0 & 1 & 1 & 1 & 4 \\
\hline 6 & HCE/B & 1 & 1 & 1 & 1 & 1 & 1 & 1 & 1 & 1 & 1 & 1 & 1 & 12 \\
\hline 7 & DTS & 1 & 1 & 1 & 1 & 1 & 0 & 1 & 1 & 1 & 1 & 1 & 1 & 11 \\
\hline 8 & $\mathrm{CM} / \mathrm{SO}$ & 1 & 0 & 1 & 1 & 1 & 1 & 1 & 1 & 1 & 1 & 1 & 1 & 10 \\
\hline 9 & TDA & 1 & 0 & 1 & 0 & 1 & 0 & 0 & 0 & 1 & 0 & 1 & 0 & 5 \\
\hline 10 & ADT & 1 & 0 & 1 & 0 & 1 & 0 & 0 & 0 & 1 & 1 & 1 & 1 & 7 \\
\hline 11 & CCA & 1 & 0 & 1 & 0 & 1 & 0 & 0 & 0 & 1 & 1 & 1 & 1 & 4 \\
\hline 12 & PC & 1 & 0 & 1 & 0 & 1 & 0 & 0 & 0 & 1 & 0 & 1 & 1 & 4 \\
\hline De.P & & 12 & 4 & 11 & 5 & 11 & 3 & 5 & 5 & 11 & 9 & 11 & 10 & \\
\hline
\end{tabular}

Fig 4.2.3 : Final reachability matrix

D.P : Driving power ; De.P : dependence power

\subsection{Level Partition [case 1 ]}

From the final reachability matrix, reachability and final antecedent set for each factor are found. The elements for which the reachability and intersection sets are same are the top-level element in the ISM hierarchy. After the identification of top level element, it is separated out from the other elements and the process continues for next level of elements. Reachability set, antecedent set, intersection set along with different level for elements have been shown below in table 4.3.1. 
Table 4.3.1: Iteration I

\begin{tabular}{|c|c|c|c|c|}
\hline $\begin{array}{c}\text { S.No } \\
\text {. }\end{array}$ & $\begin{array}{l}\text { Reachabili } \\
\text { ty set }\end{array}$ & $\begin{array}{c}\text { Antecedent } \\
\text { set }\end{array}$ & $\begin{array}{l}\text { Intersect } \\
\text { ion set }\end{array}$ & Level \\
\hline 1. & 5,7 & $\begin{array}{c}1,2,3,4,5,6,7,8 \\
, 9,10,11,12,13 \\
, 14\end{array}$ & 5,7 & \multirow{8}{*}{ I } \\
\hline 2. & $5,6,7,8$ & $\begin{array}{l}1,2,3,4,6,8,9,1 \\
0,11,12,13,14\end{array}$ & $5,6,7,8$ & \\
\hline 3. & $\begin{array}{c}3,5,6,7,8,9 \\
10,14\end{array}$ & $\begin{array}{c}1,2,3,4,9,10,1 \\
1,12,13,14\end{array}$ & $3,9,10,14$ & \\
\hline 4. & $\begin{array}{c}3,5,6,7,8,9 \\
10,13,14\end{array}$ & $\begin{array}{c}1,2,3,4,9,10,1 \\
1,12,13\end{array}$ & $3,9,10,13$ & \\
\hline 5. & $\begin{array}{c}3,5,6,7,8,9 \\
10,11,12,1 \\
3,14\end{array}$ & $\begin{array}{c}1,2,3,4,9,10,1 \\
1,12\end{array}$ & $\begin{array}{l}3,9,10,11 \\
\quad, 12\end{array}$ & \\
\hline 6. & $\begin{array}{c}3,4,5,6,7,8, \\
9,10,11,13, \\
14\end{array}$ & $1,2,4,9,11,12$ & $3,4,9,12$ & \\
\hline 7. & $\begin{array}{c}2,3,4,5,6,7, \\
8,9,10,11,1 \\
3,14\end{array}$ & 1,2 & 2 & \\
\hline 8 & $\begin{array}{c}1,2,3,4,5,6 \\
7,8,9,10,11 \\
, 13,14\end{array}$ & 1 & 8 & \\
\hline
\end{tabular}

Table 4.3.2: Iteration II

\begin{tabular}{|c|c|c|c|c|}
\hline $\begin{array}{c}\text { S.No } \\
\text {. }\end{array}$ & $\begin{array}{l}\text { Reachabili } \\
\text { ty set }\end{array}$ & $\begin{array}{c}\text { Antecedent } \\
\text { set }\end{array}$ & $\begin{array}{l}\text { Intersect } \\
\text { ion set }\end{array}$ & Level \\
\hline 2. & 6,8 & $\begin{array}{l}1,2,3,4,6,8,9,1 \\
0,11,12,13,14\end{array}$ & 6,8 & \multirow{7}{*}{ II } \\
\hline 3. & $\begin{array}{c}3,6,8,9,10 \\
14\end{array}$ & $\begin{array}{c}1,2,3,4,9,10,1 \\
1,12,13,14\end{array}$ & $3,9,10,14$ & \\
\hline 4. & $\begin{array}{c}3,6,8,9,10 \\
13,14\end{array}$ & $\begin{array}{c}1,2,3,4,9,10,1 \\
1,12,13\end{array}$ & $3,9,10,13$ & \\
\hline 5. & $\begin{array}{c}3,6,8,9,10 \\
11,12,13,1 \\
4\end{array}$ & $\begin{array}{c}1,2,3,4,9,10,1 \\
1,12\end{array}$ & $\begin{array}{c}3,9,10,11 \\
, 12\end{array}$ & \\
\hline 6. & $\begin{array}{l}3,4,6,8,9,1 \\
0,11,13,14\end{array}$ & $1,2,4,9,11,12$ & $3,4,9,12$ & \\
\hline 7. & $\begin{array}{c}2,3,4,6,8,9 \\
10,11,13,1 \\
4\end{array}$ & 1,2 & 2 & \\
\hline 8 & $\begin{array}{c}1,2,3,4,6,8, \\
9,10,11,13, \\
14\end{array}$ & 1 & 1 & \\
\hline
\end{tabular}

Table 4.3.3: Iteration III

\begin{tabular}{|c|c|c|c|c|}
\hline $\begin{array}{c}\text { S.No } \\
\text {. }\end{array}$ & $\begin{array}{c}\text { Reachabili } \\
\text { ty set }\end{array}$ & $\begin{array}{l}\text { Antecedent } \\
\text { set }\end{array}$ & $\begin{array}{c}\text { Intersect } \\
\text { ion set }\end{array}$ & Level \\
\hline 3. & $3,9,10,14$ & $\begin{array}{c}1,2,3,4,9,10,1 \\
1,12,13,14\end{array}$ & $3,9,10,14$ & \\
\hline 4. & $3,9,10,13,1$ & $1,2,3,4,9,10,1$ & $3,9,10,13$ & \\
\hline
\end{tabular}

\begin{tabular}{|c|c|c|c|c|}
\hline & 4 & $1,12,13$ & & \multirow{5}{*}{ III } \\
\hline 5. & $\begin{array}{c}3,9,10,11,1 \\
2,13,14\end{array}$ & $\begin{array}{c}1,2,3,4,9,10,1 \\
1,12\end{array}$ & $\begin{array}{c}3,9,10,11 \\
, 12\end{array}$ & \\
\hline 6. & $\begin{array}{c}3,4,9,10,11 \\
, 13,14\end{array}$ & $1,2,4,9,11,12$ & $3,4,9,12$ & \\
\hline 7. & $\begin{array}{c}2,3,4,9,10, \\
11,13,14\end{array}$ & 1,2 & 2 & \\
\hline 8 & $\begin{array}{l}1,2,3,4,9,1 \\
0,11,13,14\end{array}$ & 1 & 1 & \\
\hline
\end{tabular}

Table 4.3.4: Iteration IV

\begin{tabular}{|c|c|c|c|c|}
\hline $\begin{array}{c}\text { S.No } \\
\text {. }\end{array}$ & $\begin{array}{c}\text { Reachabili } \\
\text { ty set }\end{array}$ & $\begin{array}{c}\text { Antecedent } \\
\text { set }\end{array}$ & $\begin{array}{c}\text { Intersect } \\
\text { ion set }\end{array}$ & Level \\
\hline 4. & 13 & $1,2,4,11,12,13$ & 13 & \multirow{5}{*}{ IV } \\
\hline 5. & $\begin{array}{c}3,9,10,11,1 \\
2,13,14\end{array}$ & $\begin{array}{c}1,2,3,4,9,10,1 \\
1,12\end{array}$ & $\begin{array}{c}3,9,10,11 \\
, 12\end{array}$ & \\
\hline 6. & $\begin{array}{c}3,4,9,10,11 \\
, 13,14\end{array}$ & $1,2,4,9,11,12$ & $3,4,9,12$ & \\
\hline 7. & $\begin{array}{c}2,3,4,9,10 \\
11,13,14\end{array}$ & 1,2 & 2 & \\
\hline 8 & $\begin{array}{l}1,2,3,4,9,1 \\
0,11,13,14\end{array}$ & 1 & 1 & \\
\hline
\end{tabular}

Table 4.3.5: Iteration V

\begin{tabular}{|c|c|c|c|c|}
\hline $\begin{array}{c}\text { S.No } \\
\cdot\end{array}$ & $\begin{array}{c}\text { Reachabili } \\
\text { ty set }\end{array}$ & $\begin{array}{c}\text { Antecedent } \\
\text { set }\end{array}$ & $\begin{array}{c}\text { Intersect } \\
\text { ion set }\end{array}$ & Level \\
\hline 5. & $\mathbf{1 1 , 1 2}$ & $1,2,4,11,12$ & $\mathbf{1 1 , 1 2}$ & \multirow{2}{*}{} \\
\cline { 1 - 3 } 6. & 4,11 & $1,2,4,9,11,12$ & 4,12 & \multirow{2}{*}{$\mathbf{V}$} \\
\hline 7. & $2,4,11$ & 1,2 & 2 & \\
\hline 8 & $1,2,4,11$ & 1 & 1 & \\
\hline
\end{tabular}

Table 4.3.6: Iteration VI

\begin{tabular}{|c|c|c|c|c|}
\hline $\begin{array}{c}\text { S.No } \\
\cdot\end{array}$ & $\begin{array}{c}\text { Reachabili } \\
\text { ty set }\end{array}$ & $\begin{array}{c}\text { Antecedent } \\
\text { set }\end{array}$ & $\begin{array}{c}\text { Intersect } \\
\text { ion set }\end{array}$ & Level \\
\hline 6. & 4 & $1,2,4,9$ & 6. & \\
\cline { 1 - 3 } & 2,4 & 1,2 & 7. & \multirow{2}{*}{ VI } \\
\hline 8 & $1,2,4$ & 1 & 8 & \\
\hline
\end{tabular}

Table 4.3.7: Iteration VII

\begin{tabular}{|c|c|c|c|c|}
\hline $\begin{array}{c}\text { S.No } \\
\cdot\end{array}$ & $\begin{array}{c}\text { Reachabili } \\
\text { ty set }\end{array}$ & $\begin{array}{c}\text { Antecedent } \\
\text { set }\end{array}$ & $\begin{array}{c}\text { Intersect } \\
\text { ion set }\end{array}$ & Level \\
\hline 7. & $\mathbf{2}$ & 1,2 & $\mathbf{2}$ & \multirow{2}{*}{ VII } \\
\hline 8 & 1,2 & 1 & 1 & \\
\hline
\end{tabular}


Table 4.3.8: Iteration VIII

\begin{tabular}{|c|c|c|c|c|}
\hline $\begin{array}{c}\text { S.No } \\
\cdot\end{array}$ & $\begin{array}{c}\text { Reachabili } \\
\text { ty set }\end{array}$ & $\begin{array}{c}\text { Antecedent } \\
\text { set }\end{array}$ & $\begin{array}{c}\text { Intersect } \\
\text { ion set }\end{array}$ & Level \\
\hline 8 & 1 & 1 & 1 & VIII \\
\hline
\end{tabular}

\subsection{Level partition ( Case 2 )}

Table 4.4.1: Iteration I

\begin{tabular}{|c|c|c|c|c|}
\hline $\begin{array}{c}\text { S.No } \\
\text {. }\end{array}$ & $\begin{array}{l}\text { Reachabili } \\
\text { ty set }\end{array}$ & $\begin{array}{c}\text { Antecedent } \\
\text { set }\end{array}$ & $\begin{array}{c}\text { Intersect } \\
\text { ion set }\end{array}$ & Level \\
\hline 1. & 1 & $\begin{array}{c}1,2,3,4,5,6,7,8 \\
, 9,10,11,12\end{array}$ & 1 & \multirow{7}{*}{ I } \\
\hline 2. & $1,3,5,9,11$ & $\begin{array}{c}2,3,4,5,6,7,8,9 \\
, 10,11,12\end{array}$ & $3,5,9,11$ & \\
\hline 3. & $\begin{array}{c}1,3,5,9,11, \\
12\end{array}$ & $\begin{array}{c}2,4,6,7,8,10,1 \\
1,12\end{array}$ & 11,12 & \\
\hline 4. & $\begin{array}{c}1,3,5,9,10, \\
12\end{array}$ & $\begin{array}{c}2,4,6,7,8,10,1 \\
1\end{array}$ & 10 & \\
\hline 5. & $\begin{array}{c}1,3,5,7,8,9, \\
10,12\end{array}$ & $2,4,6,7,8$ & 7,8 & \\
\hline 6. & $\begin{array}{c}1,3,4,5,6,7 \\
8,9,10,12\end{array}$ & $2,4,6,8$ & $4,6,8$ & \\
\hline 7. & $\begin{array}{l}1,2,3,4,5,6, \\
7,8,9,10,12\end{array}$ & $2,4,6$ & $2,4,6$ & \\
\hline
\end{tabular}

Table 4.4.2: Iteration II

\begin{tabular}{|c|c|c|c|c|}
\hline $\begin{array}{c}\text { S.No } \\
\text {. }\end{array}$ & $\begin{array}{l}\text { Reachabili } \\
\text { ty set }\end{array}$ & $\begin{array}{c}\text { Antecedent } \\
\text { set }\end{array}$ & $\begin{array}{c}\text { Intersect } \\
\text { ion set }\end{array}$ & Level \\
\hline 2. & $3,5,9,11$ & $\begin{array}{c}2,3,4,5,6,7,8,9 \\
, 10,11,12\end{array}$ & $3,5,9,11$ & \multirow{6}{*}{ II } \\
\hline 3. & $\begin{array}{c}1,3,5,9,11 \\
12\end{array}$ & $\begin{array}{c}2,4,6,7,8,10,1 \\
1,12\end{array}$ & 11,12 & \\
\hline 4. & $\begin{array}{c}1,3,5,9,10 \\
12\end{array}$ & $\begin{array}{c}2,4,6,7,8,10,1 \\
1\end{array}$ & 10 & \\
\hline 5. & $\begin{array}{c}1,3,5,7,8,9, \\
10,12\end{array}$ & $2,4,6,7,8$ & 7,8 & \\
\hline 6. & $\begin{array}{c}1,3,4,5,6,7 \\
8,9,10,12\end{array}$ & $2,4,6,8$ & $4,6,8$ & \\
\hline 7. & $\begin{array}{l}1,2,3,4,5,6, \\
7,8,9,10,12\end{array}$ & $2,4,6$ & $2,4,6$ & \\
\hline
\end{tabular}

Table 4.4.3: Iteration III

\begin{tabular}{|c|c|c|c|c|}
\hline $\begin{array}{c}\text { S.No } \\
\cdot\end{array}$ & $\begin{array}{c}\text { Reachabili } \\
\text { ty set }\end{array}$ & $\begin{array}{c}\text { Antecedent } \\
\text { set }\end{array}$ & $\begin{array}{c}\text { Intersect } \\
\text { ion set }\end{array}$ & Level \\
\hline 3. & $\mathbf{1 2}$ & $\begin{array}{c}2,4,6,7,8,10,1 \\
1,12\end{array}$ & 11,12 & \multirow{2}{*}{} \\
\cline { 1 - 3 } & & 10,12 & $\begin{array}{c}2,4,6,7,8,10,1 \\
1\end{array}$ & \multirow{2}{*}{ III } \\
\cline { 1 - 3 } 5. & $7,8,10,12$ & $2,4,6,7,8$ & 7,8 & \\
\hline 6. & $4,6,7,8,10$, & $2,4,6,8$ & $4,6,8$ & \\
\hline
\end{tabular}

\begin{tabular}{|c|c|l|l|l|}
\hline & 12 & & & \\
\hline 7. & $2,4,6,7,8$, & $2,4,6$ & $2,4,6$ & \\
& 10,12 & & & \\
\hline
\end{tabular}

Table 4.4.4: Iteration IV

\begin{tabular}{|c|c|c|c|c|}
\hline $\begin{array}{c}\text { S.No } \\
\text {. }\end{array}$ & $\begin{array}{l}\text { Reachabili } \\
\text { ty set }\end{array}$ & $\begin{array}{l}\text { Antecedent } \\
\text { set }\end{array}$ & $\begin{array}{c}\text { Intersect } \\
\text { ion set }\end{array}$ & Level \\
\hline 4. & 10 & $\begin{array}{c}2,4,6,7,8,10,1 \\
1\end{array}$ & 4. & \multirow{4}{*}{ IV } \\
\hline 5. & $7,8,10$ & $2,4,6,7,8$ & 5. & \\
\hline 6. & $4,6,7,8,10$ & $2,4,6,8$ & 6. & \\
\hline 7. & $\begin{array}{c}2,4,6,7,8,1 \\
0\end{array}$ & $2,4,6$ & 7. & \\
\hline
\end{tabular}

Table 4.4.5: Iteration $\mathrm{V}$

\begin{tabular}{|c|c|c|c|c|}
\hline $\begin{array}{c}\text { S.No } \\
\text { • }\end{array}$ & $\begin{array}{c}\text { Reachabili } \\
\text { ty set }\end{array}$ & $\begin{array}{c}\text { Antecedent } \\
\text { set }\end{array}$ & $\begin{array}{c}\text { Intersect } \\
\text { ion set }\end{array}$ & Level \\
\hline 5. & $\mathbf{7 , 8}$ & $2,4,6,7,8$ & 7,8 & \multirow{2}{*}{ V } \\
\cline { 1 - 3 } 6. & $4,6,7,8$ & $2,4,6,8$ & $4,6,8$ & \\
\hline 7. & $2,4,6,7,8$ & $2,4,6$ & $2,4,6$ & \\
\hline
\end{tabular}

Table 4.4.6: Iteration VI

\begin{tabular}{|c|c|c|c|c|}
\hline $\begin{array}{c}\text { S.No } \\
\cdot\end{array}$ & $\begin{array}{c}\text { Reachabili } \\
\text { ty set }\end{array}$ & $\begin{array}{c}\text { Antecedent } \\
\text { set }\end{array}$ & $\begin{array}{c}\text { Intersect } \\
\text { ion set }\end{array}$ & Level \\
\hline 6. & $\mathbf{4 , 6}$ & $2,4,6$ & 4,6 & \multirow{2}{*}{ VI } \\
\hline 7. & $2,4,6$ & $2,4,6$ & $2,4,6$ & \\
\hline
\end{tabular}

Table 4.4.7: Iteration VII

\begin{tabular}{|c|c|c|c|c|}
\hline $\begin{array}{c}\text { S.No } \\
\cdot\end{array}$ & $\begin{array}{c}\text { Reachabili } \\
\text { ty set }\end{array}$ & $\begin{array}{c}\text { Antecedent } \\
\text { set }\end{array}$ & $\begin{array}{c}\text { Intersect } \\
\text { ion set }\end{array}$ & Level \\
\hline 7. & 2 & 2 & 2 & VII \\
\hline
\end{tabular}




\subsection{Driving power and dependence diagram [ Case 1]}

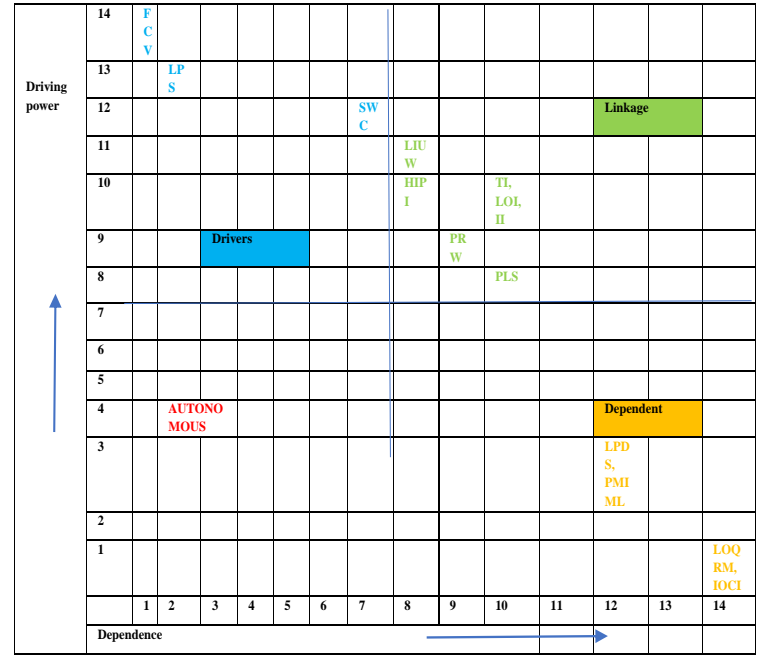

\subsection{Driving power and dependence diagram [Case-2]}

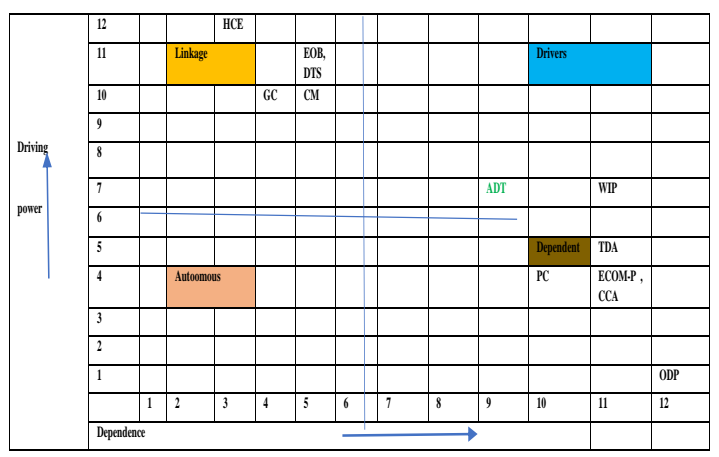

\subsection{ISM Diagraph}

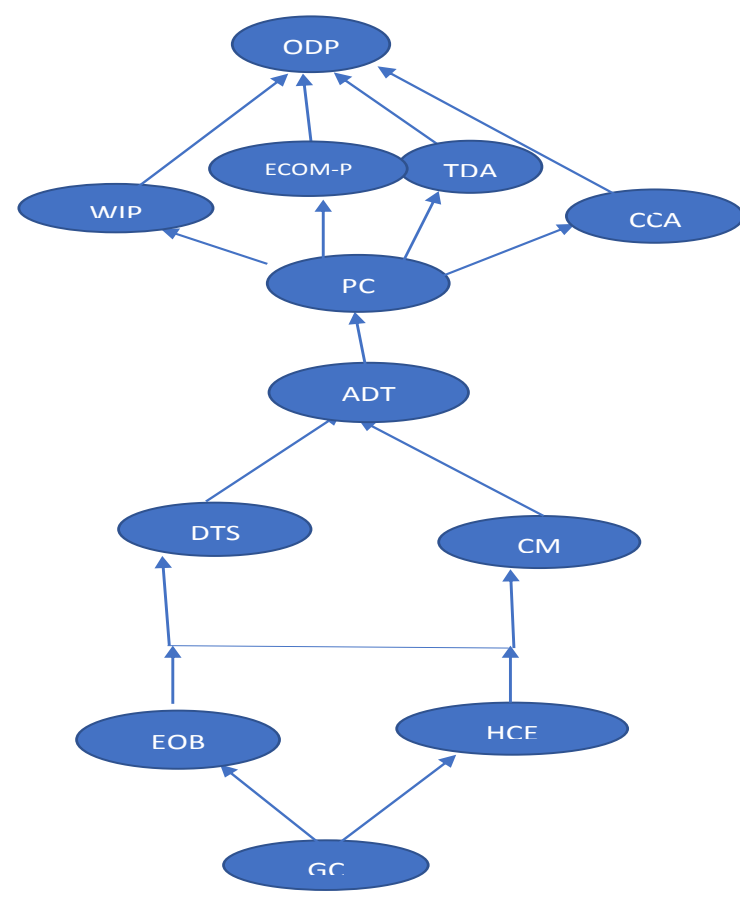

Figure 1 : ISM Diagraph

\section{FUTURE DIRECTIONS}

\subsection{Theory of innovations in handloom / weaving industry [18]}

By analyzing hand-loom weaving as a socio-technology, weaving communities are constantly innovating their technologies, designs, markets, and social organization-often without calling it innovation.

\subsection{Quantitative Approach}

Various other methodologies such as AHP , Fuzzy AHP etc. can be used in addition to ISM methodology .

\section{ACKNOWLEDGEMENTS}

Authors are thankful to Prof. S.P. Singh for disseminating the knowledge about ISM methodology and also to the handloom sector and its manpower of India and Bangladesh for the inspiration to conduct this research work. Our thanks to the anonymous reviewers of the manuscript .

\section{REFERENCES}

[1] Banarjee, S.; Muzib, M. M. and Sharmin, S. 2014. Status of Handloom Workers and Causes of Their Migration: A Study in Handloom Industry of Tangail District, Bangladesh, Research on Humanities and Social Sciences, 4(22).

[2] Bangladesh Bureau of Statistics (BBS). 2005. Report on Bangladesh Handloom Census 2003.Dhaka: Planning Division, Ministry of Planning.

[3] Bangladesh Export Promotion Bureau (EPB). 2006-07. Bangladesh Export Statistics. Dhaka: Export Promotion Bureau.

[4] http://www.epb.gov.bd/index.php?NoParameter\&Theme $=$ default $\&$ Script $=$ publication.

[5] Bangladesh Handloom Board 2012. 'Profile', Report, Bangladesh Handloom Board Profile, BHB, BHB, Dhaka.

[6] Bhattacharjee, D. and Khaled, M. 1969. Marketing of Small Industries Products in East Pakistan.Dhaka: Bureau of Economic Research, Dhaka University.

[7] BHB 2012. 'Importance of Handlooms in Bangladesh', Article, Bangladesh Handloom Board, Bangladesh Handloom Board, Bangladesh Handloom Board, Dhaka.

[8] Islam, M. K. and Hossain, M. E. 2015. Determinants of Technical Inefficiency of Handloom Weaving Industry in Kushtia District of Bangladesh: A Tobit Model Approach, Journal of Investment and Management, 4(4), 95-99.

[9] Jaforulla, M. 1999. Production Technology, Elasticity of Substitution and Technical Efficiency of the Handloom Textile Industry of Bangladesh. Applied Economics, 31(4), 437-442.

[10] Latif, M.A. 1997. Handloom Industry of Bangladesh 1947-1990. Dhaka: University Press Ltd.

[11] Islam, M. K. and Hossain, M. E. 2015. Determinants of Technical Inefficiency of Handloom Weaving Industry in Kushtia District of Bangladesh: A Tobit Model Approach, Journal of Investment and Management, 4(4), 95-99.

[12] Khondoker,A. M and Sonobe, T. 2011. Determinants of Small Enterprises' Performance in Developing Countries: 
A Bangladesh Case, The National Graduate Institute For Policy Studies (GRIPS), Tokyo. https://mpra.ub.unimuenchen.de/44006/

[13] Liton, M.R.I, Islam, T., Saha, S. 2016. Present Scenario and Future Challenges in Handloom Industry in Bangladesh. Social Sciences , 5(5) , 70-76. doi: 10.11648/j.ss.20160505.12

[14] Khatoon , S. 2016. Make in India : A platform to Indian Handloom market, IOSR Journal of business and management (IOSR-IBM). e-ISSN : 2278-487X, 18(9), $36-40$.

[15] Buhler, A. Fischer, E. and Nobholz, M. L. 1980. Indian Tie - Dyed Fabrics , 4, P.20.
[16] Mohanty, B. C. and Krishna, K. 1974. Ikat Fabrics of Orissa and Andhra Pradesh , 1, Calico Museum of Textiles, Ahmedabad, India, P. 18.

[17] Mohanty, B. C. and Krishna, K. 1974. Ikat Fabrics of Orissa and Andhra Pradesh , 1, Calico Museum of Textiles, Ahmedabad, India , P. 15.

[18] Meheta, R. N. 1961. Bandhas of Orissa, Journal of Indian Textile History, VII, Ahmedabad, P-68.

[19] Warfield , J.N. 1974. Developing interconnection matrices in structural modeling. In the proceedings of IEEE Transactions on System, Man, and Cybernetics (SMC), 4 (1), 81-87.

[20] Mamidipudi , A. and Bijker, W.E. 2018. Innovation in Indian Handloom Weaving, Technology and Culture 59(3), 509-545 . 